This item was submitted to Loughborough's Research Repository by the author.

Items in Figshare are protected by copyright, with all rights reserved, unless otherwise indicated.

\title{
Practical scepticism
}

PLEASE CITE THE PUBLISHED VERSION

http://dx.doi.org/10.1177/09579265030146007

PUBLISHER

(c) Sage

VERSION

AM (Accepted Manuscript)

LICENCE

CC BY-NC-ND 4.0

REPOSITORY RECORD

Potter, Jonathan. 2019. "Practical Scepticism". figshare. https://hdl.handle.net/2134/15079. 
This item was submitted to Loughborough's Institutional Repository (https://dspace.lboro.ac.uk/) by the author and is made available under the following Creative Commons Licence conditions.

\section{creative
commons}

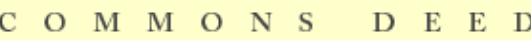

Attribution-NonCommercial-NoDerivs 2.5

You are free:

- to copy, distribute, display, and perform the work

Under the following conditions:

Attribution. You must attribute the work in the manner specified b the author or licensor.

Noncommercial. You may not use this work for commercial purposes.

No Derivative Works. You may not alter, transform, or build upon this work.

- For any reuse or distribution, you must make clear to others the license terms of this work.

- Any of these conditions can be waived if you get permission from the copyright holder.

Your fair use and other rights are in no way affected by the above.

This is a human-readable summary of the Leqal Code (the full license).

\section{Disclaimer 만}

For the full text of this licence, please go to: http://creativecommons.org/licenses/by-nc-nd/2.5/ 


\section{PRACTICAL SCEPTICISM}

\section{JONATHAN POTTER}

Discourse and Rhetoric Group

Department of Social Sciences

Loughborough University

Loughborough

Leicestershire, LE11 3TU
Email:J.A.Potter@lboro.ac.uk

Tel: 01509223384

Fax: 01509223944

Key words: discourse analysis, discursive psychology, constructionism, methods

Published as:

Potter, J. (2003). Practical scepticism, Discourse \& Society, 14, 799-801. 
Hopefully this friendly exchange between Martyn Hammersley and I has clarified some issues. Some of the muddier points will have to wait for another day before being polished up. And others reflect different images of social research that are unlikely to be reconciled. However, it is worth devoting a little further consideration to questions of construction and reality.

Hammersley suggests that Representing Reality (Potter, 1996) equivocates between a methodological and a philosophical relativism. I see it rather as setting aside philosophical arguments about relativism (which are strongly pressed, of course, in Edwards et al., 1995) in order to focus on the development of a systematic constructionist position. One of the confusions in a lot of constructionist work, and in (often understandable) critiques of constructionism, is the idea that showing that a description is constructed amounts to showing that it is not true. Representing Reality's systematic, and symmetrical constructionist position argues that researchers should consider all accounts, descriptions, versions and so as constructed (out of words, idioms, categories, repertoires and so on). Its topic is how descriptions are constructed, in particular sequences and settings, in a way that is oriented to a range of actions.

Hammersley suggests I use a variation on an ancient sceptic argument that 'to judge whether a representations is accurate we would have to be able to compare it to reality, yet we have not access to reality itself only to accounts of it' and he suggests I make the epistemic inference that 'only knowledge claims whose validity has been demonstrated beyond all possible doubt can be accepted as true' (2003: ${ }^{* *}$. Let me emphasise that the arguments here have a methodological focus. Rather than being a sceptic's thought experiment this is the practical situation that faces discourse researchers. As such we are not in a position of being able to compare 
representations to reality; rather we are comparing different representations: of partners in a relationship, say, or of a police officer and suspect. Whatever the philosophical implications, this provides a coherent and practical basis for studying descriptions and how they are constructed.

Mapping the Language of Racism (Wetherell and Potter, 1992) predates Representing Reality. However, despite Hammersley's strong assertions to the opposite I don't think it is radically inconsistent with the perspective developed in that book. It not written as a 'pure' piece of discourse analysis - it includes an ethnographic strand of analysis of interviews and documents. However, it is not offering a realist history of New Zealand and its racial conflicts. We made that point strongly, for example, with the issue of the 'discovery' of New Zealand:

We do want to argue that there is a crucial sense in which 'New Zealand' didn't actually exist until it was discovered. Then, when it was discovered by Polynesian voyagers, by Abel Tasman and most recently by Captain Cook (and given various different names), it became several different objects. As Brannigan (1981) has pointed out for the discovery of America, there are sometimes a range of competing discovery claims. But these are not claims to have discovered the same object; rather the precise definition of what the object is, is the outcome of the process of discovery, definition and articulation (Woolgar, 1988) (Wetherell and Potter, 1992: 64).

In general, the historical narrative, the social groupings and interests and so on that are discussed are integral to the analysis, yes, but they are not excluded from issues of construction. Nor are they prerequisites for the analysis. They aid its interpretation, and help guide its implications for New Zealand. 
Intentions are subject to the same sort of consideration. Hammersley claims that 'even to describe an action as, for example, a stake inoculation is not only to attribute an intention, in some sense of that word, but also to hint at motives that the person concerned might have had for engaging in this action' (2003: $\left.{ }^{* *}\right)$. This is precisely the kind of cognitivism that discursive psychology has criticised over a long period. Whether or not stake inoculation suggests some sense of intention and hints at motive, these things are not being used to explain what is going on. In DP they appear as topic. As Edwards and Potter (in press) write:

the main thrust of DP is not to close down psychology departments, but to counter and invert what mainstream psychology has done with discourse, which is to treat it as the expression of thoughts, intentions and cognitive structures. The 'inversion' offered by DP is to start with discourse itself, and to see how all of those presumptively prior and independent notions of mind, intention, motive, etc., are topicalized, categorized and, in various less direct ways, handled and managed within discourse itself (in press: **).

As I have noted before, this is not the only programmatic way of approaching discourse. However, it is coherent and it has been honed in over a decade of research studies. The strongest test is its ability to provide striking analyses of particular phenomena and to provide more coherent, detailed and generative analyses than alternative available approaches from within and outwith discourse analysis.

\section{References}

Brannigan, A. (1981). The social basis of scientific discoveries. Cambridge: Cambridge University Press. 
Edwards, D. \& Potter, J. (forthcoming). Discursive psychology, mental states and descriptions. In H. te Molder \& J. Potter (Eds). Talk and cognition: Discourse, mind and social interaction. Cambridge; Cambridge University Press.

Edwards, D., Ashmore, M. \& Potter, J. (1995). Death and furniture: The rhetoric, politics, and theology of bottom line arguments against relativism. History of the Human Sciences, 8 (2), 25-49.

Hammersley, M. (2003). Doing the fine thing: A rejoinder to Jonathan Potter, Discourse and Society, ${ }^{*},{ }^{* *}{ }_{-}^{* *}$.

Potter, J. (1996) Representing Reality: Discourse, Rhetoric and Social Construction. London; Sage.

Woolgar, S. (1988). Science: The very idea. Chichester: Ellis Horwood./ London: Tavistock.

JONATHAN POTTER has researched a range of topics including racism, relationship counselling, and child protection helplines and has written extensively on metatheory, theory and methods in the area of discourse analysis and discursive psychology. His most recent books are Representing Reality (Sage, 1996), Focus Group Practice (with Claudia Puchta, Sage, in press) and Talk and Cognition (edited with Hedwig te Molder, CUP, in press). He is Professor of Discourse Analysis at Loughborough University. 